\title{
B2B Marketing Strategies to Gain Competitive Advantage in Coimbatore Based Pump Industry in Tamilnadu
}

\author{
Rajkumar.S, J.Clement Sudhahar , T.S.Venkateswaran
}

\begin{abstract}
Marketing excellence is the need of the hour in today's competitive scenario. Numerous companies are striving to compete by continuous implementation of effective marketing strategies for sustainable growth. The purpose of this research is to investigate the impact of Internal marketing strategies and analyse the relationship between Focus Strategy (FS), Differentiation Strategy (DS), Market Penetration Strategy (MPS) and Sales Service Support Strategy (SSS) for Competitive Advantage (CA) with respect to organised sector of Coimbatore based pump industry in TamilNadu.The result shows that, Focus Strategy, Differentiation Strategy and Sales Service Support Strategy are having strong and positive impact on Market Penetration Strategies. There is also a positive and strong impact of Market Penetration Strategy for Competitive Advantage. It was suggested to provide adequate training for sales and service persons to constantly improve on technical expertise and look for new design of service quality and to monitor on-time service which would place organized pump industry on sustainable growth in a competitive market.
\end{abstract}

Keywords: B2B Marketing Strategy, Competitive Advantage, SustainableGrowth in Pump Industry.

\section{INTRODUCTION}

India has always been a predominantly agrarian country. Agriculture Accounts for about $1 / 5^{\text {th }}$ of the national income. It is the most important resources of support for the growth of Gross Domestic Product (GDP). Agriculture has always been India's most important economic sector. Keeping the demand management in mind, this research has been carried out to analyse the significant impact of marketing strategies to gain competitive advantages and thus this research would help the marketers and pump dealer's to better appreciate and recognize the influencing factors for the growth of agricultural pump-set market andto examine the effect of marketing strategies to gain competitive advantage in Coimbatore based pump industry in Tamilnadu.

Revised Manuscript Received on October 10, 2019.

* Correspondence Author

RajKumar.S*, PhD, Management, Bharathiar University, Coimbatore641046

Dr.J.Clement Sudhahar, Professor, Marketing and Decision Strategy, Head, Karunya School of Management, Karunya University, Coimbatore 641114.

Dr. T. S. Venkateswaran, Head, Department of MCA \& Placement Officer KSR College of Arts \& Science (A), Tiruchengode - 637215

(c) The Authors. Published by Blue Eyes Intelligence Engineering and Sciences Publication (BEIESP). This is an open access article under the CC BY-NC-ND license (http://creativecommons.org/licenses/by-nc-nd/4.0/)

\section{STATEMENT OF THE PROBLEM}

The Central and State Governments have been lending a supporting role particularly marketing of energy-efficient pump sets. Keeping the demand management in mind, this research has been carried out to analyse the significant impact of marketing strategies to build competitive advantages and thus this research would help the marketers and pump dealer's to better appreciate and recognize the influencing factors for the growth of agricultural pump-set market. Hence, there is a need to find answer to the following questions.

\section{A. Objectives of the Study}

1. To understand the organised pump sector marketer's profile in Coimbatore based pump industry

2. To study the relationship between focus strategy and market penetration strategy with respect to pump market.

3. To examine the relationship between differentiation strategy and market penetration strategy.

4. To investigate the relationship between the sales service support strategy and market penetration strategy.

5. To analyse the relationship on market penetration strategy for competitive advantage.

6. To suggest suitable model for sustainable growth in a competitive environment.

\section{B. Research Design and Sample Size}

Descriptive research is adopted by the researcher to study hence it describes the state it exists at present era. Both secondary and primary data are collected and implanted in this current study. The target population for this study was primarily, dealers and retailers associated with the agricultural sector pump industries in Coimbatore district, dealing with end suction pumps, bore well submersible and open well submersible pump sets etc. The respondents are in the capacity of Managing Directors, Proprietors, Partners etc. in the key positions as dealers and retailers of the organized pump sector firms that operate primarily in Coimbatore district and other targeted territories as mentioned above in Tamilnadu. The list of 374 dealers and retailers were obtained from South Indian pump manufactures association and the related directory was deemed as a reliable sample frame.

Published By:

Blue Eyes Intelligence Engineering \& Sciences Publication (C) Copyright: All rights reserved. 


\section{C.Statistical Tools Used For Analysis}

In respect to pump industry and their applications for marketing strategy to gain competitive advantage on their observed variables, gender, positions, age, educational qualification, brand products, market region, types of trade, revenue growth, cross tabulation were studied by percentages, chi-square test, anova, multiple regression techniques. Also, factor analysis and SEM were used.

\section{REVIEW OF LITERATURE}

Premkumar and Balamurugan (2012) capturing a reasonable market share in competitive environment requires more than implementing plain production techniques in an effective way. The researcher has conducted the study to identify the global marketing strategies adopted by Coimbatore pump industry. This study also highlights certain marketing issues and suggested to adopt marketers to become one-stop solution provider that is capable of providing integrated offerings through diverse range of products and service network to quality conscious customers.

Arthur Thomson and Strickland (2013) suggest that competitive advantage is usually acquired by employing a creative offensive strategy that is not easily aggravated by rivals. One of the most powerful offensive strategies is to challenge rivals with an equally good or better product at a lower price. The foremost purpose of defensive strategy is to protect competitive advantage and fortify the firm's competitive position.

Jayanthi and Amudha (2013)An empricial evidence from the pump and motor industries of Coimbatore shows that these SME operate in the international markets with careful entry by the entrepreneur's reactiveness .this research has explained the knowledge factor which are market knowledge, entrepreneurial knowledge and the operating knowledge to be vital for exporting firms. The result from selected exporting firms in Coimbatore clearly shows that the influence of experiential knowledge positively affect the firm's performance and internal growth.

RajendraNargundkar and Tapan K Panda (2015) argued that the initial strategies of the companies were targeted towards generating natural growth, but due to the Government regulations and intense competition, it has become difficult even to sustain the market share. Hence, companies started shifting their focus on Mergers and Acquisitions, Strategic Alliances and Brand Acquisitions to achieve the desired growth.

\section{DATA ANALYSIS AND INTERPRETATION}

The statistical tools - Percentage, Chi-square test, Anova and Multiple regression techniques have been used appropriately.

\section{A.Gender Classification of the Respondents}

\begin{tabular}{|c|l|c|c|c|}
\hline \multirow{2}{*}{ S.No } & \multirow{2}{*}{ Gender } & \multicolumn{3}{|c|}{ Number of the respondents } \\
\cline { 3 - 5 } & Deales & Retailers & Total \\
\hline 1 & Male & $\begin{array}{c}107 \\
(28.6 \%)\end{array}$ & $\begin{array}{c}240 \\
(64.17 \%)\end{array}$ & $\begin{array}{c}347 \\
(92.3 \%)\end{array}$ \\
\hline 2 & Female & $\begin{array}{c}12 \\
(3.20 \%)\end{array}$ & $\begin{array}{c}15 \\
(4.0 \%)\end{array}$ & $\begin{array}{c}27 \\
(7.21)\end{array}$ \\
\hline \multicolumn{2}{|c|}{ Total } & $\begin{array}{c}119 \\
(31.8 \%)\end{array}$ & $\begin{array}{c}255 \\
(68.18 \%)\end{array}$ & 374 \\
\hline
\end{tabular}

\section{B. Classification on Respondent Position}

\begin{tabular}{|c|c|c|c|c|}
\hline \multirow[b]{2}{*}{ S.No } & \multirow[b]{2}{*}{ Position } & \multicolumn{3}{|c|}{ Number of the respondents } \\
\hline & & Dealers & Retailers & Total \\
\hline 1 & $\begin{array}{l}\text { Managing } \\
\text { Director }\end{array}$ & $\begin{array}{c}6 \\
(1.6 \%)\end{array}$ & $\begin{array}{c}8 \\
(2.1 \%)\end{array}$ & $\begin{array}{c}15 \\
(4.0 \%)\end{array}$ \\
\hline 2 & $\begin{array}{c}\text { Sole } \\
\text { Proprietor }\end{array}$ & $\begin{array}{c}7 \\
(1.8 \%)\end{array}$ & $\begin{array}{c}15 \\
(4.0 \%)\end{array}$ & $\begin{array}{c}27 \\
(7.21)\end{array}$ \\
\hline 3 & Partner & $\begin{array}{c}79 \\
(21.1 \%) \\
\end{array}$ & $\begin{array}{c}208 \\
(55.6 \%) \\
\end{array}$ & $\begin{array}{c}287 \\
(76.7 \%) \\
\end{array}$ \\
\hline 4 & Executive & $\begin{array}{c}7 \\
(1.8 \%) \\
\end{array}$ & $\begin{array}{c}16 \\
(4.2 \%) \\
\end{array}$ & $\begin{array}{c}23 \\
(6.1 \%) \\
\end{array}$ \\
\hline 5 & $\begin{array}{c}\text { Sales } \\
\text { Manager }\end{array}$ & $\begin{array}{c}5 \\
(1.3 \%) \\
\end{array}$ & $\begin{array}{c}3 \\
(0.8 \%) \\
\end{array}$ & $\begin{array}{c}8 \\
(2.1 \%) \\
\end{array}$ \\
\hline 6 & $\begin{array}{c}\text { Front Office } \\
\text { Staff } \\
\end{array}$ & $\begin{array}{c}8 \\
(2.1 \%) \\
\end{array}$ & $\begin{array}{c}4 \\
(2.1 \%) \\
\end{array}$ & $\begin{array}{c}12 \\
(4.3 \%) \\
\end{array}$ \\
\hline 7 & $\begin{array}{c}\text { Sales/Service } \\
\text { Engineer }\end{array}$ & $\begin{array}{c}7 \\
(1.8 \%) \\
\end{array}$ & $\begin{array}{c}4 \\
(1.0 \%) \\
\end{array}$ & $\begin{array}{c}11 \\
(2.9 \%) \\
\end{array}$ \\
\hline & Total & $\begin{array}{c}119 \\
(31 . \%)\end{array}$ & $\begin{array}{c}255 \\
(69.2 \%) \\
\end{array}$ & 374 \\
\hline
\end{tabular}

\section{Classification Based on Product Brands}

\begin{tabular}{|c|c|c|c|c|}
\hline \multirow[b]{2}{*}{ S.No } & \multirow[b]{2}{*}{$\begin{array}{l}\text { Brand of } \\
\text { Product }\end{array}$} & \multicolumn{3}{|c|}{ Number of the respondents } \\
\hline & & Dealers & Retailes & Total \\
\hline 1 & Texmo & $\begin{array}{c}44 \\
(11.76 \%)\end{array}$ & $\begin{array}{c}104 \\
(27.8 \%)\end{array}$ & $\begin{array}{c}148 \\
(39.6 \%)\end{array}$ \\
\hline 2 & Aquatex & $\begin{array}{c}24 \\
(6.4 \%)\end{array}$ & $\begin{array}{c}83 \\
(22.2 \%)\end{array}$ & $\begin{array}{c}107 \\
(28.6 \%)\end{array}$ \\
\hline 3 & CRI & $\begin{array}{c}15 \\
(4.0 \%)\end{array}$ & $\begin{array}{c}26 \\
(6.9 \%)\end{array}$ & $\begin{array}{c}41 \\
(11.0 \%)\end{array}$ \\
\hline 4 & Suguna & $\begin{array}{c}16 \\
(4.3 \%)\end{array}$ & $\begin{array}{c}18 \\
(4.8 \%)\end{array}$ & $\begin{array}{c}34 \\
(9.0 \%)\end{array}$ \\
\hline 5 & Kirloskar & $\begin{array}{c}13 \\
(3.47 \%)\end{array}$ & $\begin{array}{c}14 \\
(3.74 \%)\end{array}$ & $\begin{array}{c}27 \\
(7.2 \%)\end{array}$ \\
\hline 6 & Deccan & $\begin{array}{c}4 \\
(1.0 \%)\end{array}$ & $\begin{array}{c}7 \\
(1.8 \%)\end{array}$ & $\begin{array}{c}11 \\
(2.9 \%)\end{array}$ \\
\hline 7 & Mahindra & $\begin{array}{c}3 \\
(0.8 \%)\end{array}$ & $\begin{array}{c}3 \\
(0.8 \%)\end{array}$ & $\begin{array}{c}6 \\
(1.6 \%)\end{array}$ \\
\hline & & $\begin{array}{c}119 \\
(31.8 \%)\end{array}$ & $\begin{array}{c}255 \\
(68.2 \%)\end{array}$ & 374 \\
\hline
\end{tabular}

D.Classification Based On Market Region and Types of Trade

\begin{tabular}{|c|c|c|c|}
\hline \multirow{2}{*}{$\begin{array}{c}\text { Market } \\
\text { Region }\end{array}$} & \multicolumn{3}{|c|}{ Trade Type } \\
\cline { 2 - 4 } & Dealers & Retailers & Total \\
\hline Coimbatore & $66(17.6 \%)$ & $162(43.3 \%)$ & $228(60.9 \%)$ \\
\hline Erode & $16(4.3 \%)$ & $25(6.7 \%)$ & $41(10.9 \%)$ \\
\hline Namakkal & $13(3.5 \%)$ & $20(5.3 \%)$ & $33(8.8 \%)$ \\
\hline Salem & $14(3.7 \%)$ & $39(10.4 \%)$ & $53(14.1 \%)$ \\
\hline Tiruppur & $10(2.7 \%)$ & $9(2.4 \%)$ & $19(5.0 \%)$ \\
\hline Total & $119(31.8 \%)$ & $255(68.2 \%)$ & 374 \\
\hline
\end{tabular}

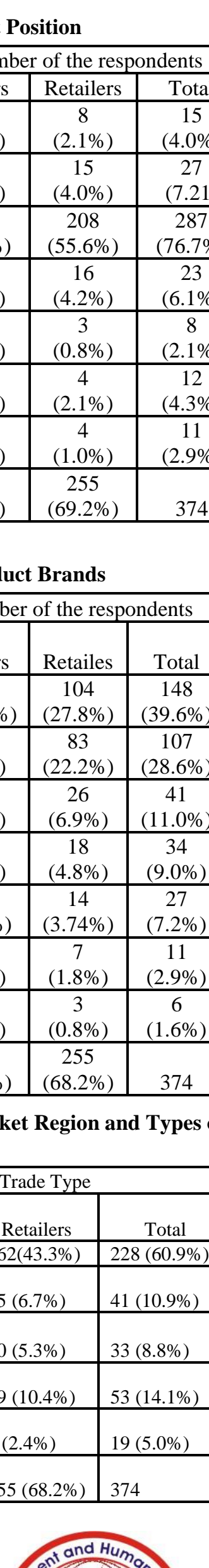




\section{V.FINDINGS \& RECOMMENDATION}

It is the responsibility of the marketing personnel's, to collect periodic market intelligence reports, to watch and monitor the movement of un-organized sectors

Tamil Nadu government has provided the free power supply to the farmers for farm equipment like motor pump sets. This should not be, miss used by any chance. This can be regularly monitored through regulatory officials, to check which unorganized manufactures and supplies any kind of non-energy efficient pump sets.

\section{IMPLICATION OF THE STUDY}

Implications for the Society The end users are the part of the public society. They enjoy the benefit of quality product at right place and right time at right price. It is suggested that they should support to the energy efficiency product to grow and sustain

Implications for the Researchers / Academicians There is a great opportunity for the researchers and academicians to bring out their analysis with cognitive dimensions in a virtual scenario through this energy efficiency movement

\section{CONCLUSION}

From the outcome of this Study, it can be concluded that the development of proven new model as referred the new model constructed has successfully achieved the desired result for effective marketing strategies to build competitive advantage with special reference to the organised Coimbatore based pump industry. Now the obligations of driving through the grass root level marketing is in the hands of each pump set marketers and all the stake holders who have the aspiration to accomplish the goal for sustainability in the competitive business environments. By means of promoting energy efficiency pump sets, the pump set manufactures and marketers have played an important role as well as the Tamilnadu government also would take the maximum benefit on energy conversation ground.

\section{VIII.SCOPE FOR FURTHER RESEARCH}

This study was primarily focused on major players in the organized pumps sector who have got their manufacturing setup in Coimbatore City mainly dealing with agricultural pump-sets.

The area of study was limited to the major districts in Tamilnadu namely Coimbatore, Erode, Tiruppur, Salem and Namakal. Future study can incorporate the other regional states with different magnitudes.

The researcher has included the various attributes related to marketing mix and competitive advantages as noted in research design. There may be other variables for competitive advantage, such as, cost leadership strategy, blue ocean strategy etc., which can be considered for future research.

\section{REFERENCES}

1. Naresh K.Malhotra,(2019). Marketing Research:An Applied Orientation, $7^{\text {th }}$ Edition,Pearson Publications.

2. Heidi Taylor, (2017).B2B Marketing Strategy: Differentiate, Develop and Deliver Lasting Customer Engagement.First Edition,Kogan Page.

3. Zabieh, L.E. Processes and mechanisms of creating and maintaining sustainable competitive advantage.

4. J. Financ. Serv. Market. Center. 2014, 21, 47-48.Dr. F.C. Sharma, (2017). Principles of Marketing.Second Edition, SBPD Publications.
5. Ren, L.; Xie, G.; Krabbendam, K. Sustainable competitive advantage and marketing innovation with in firms.Manag. Res. Rev. 2010

\section{AUTHORS PROFILE}

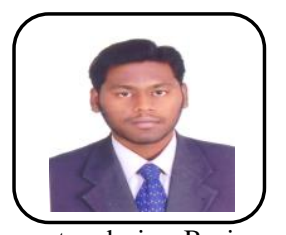

To have an opportunity to exploit my skills, knowledge and experience, gain valuable experience and demonstrate my potential to the maximum for the growth of the organization and self with 8 Years of academic experience

I have done my Graduation in Bachelor COLLEGE] with a first class grade.

On completion of these studies I've let my head in the real time Master's Researcher and have an achievement and a significant piece of research in [KARUNYA UNIVERSITY]. With this indispensible familiarity I extended my Doctorial Research [BHARATHIAR UNIVERSITY] in the area of B2B Marketing Strategies for Competitive Advantage

Though I've pursuing my career in real time research, I have a passion in teaching and mentoring people there by sharing the knowledge acquired from the real world. I believe holding lectureship position will pave way to complete knowledge management and people development.

\section{Publication of Books}

Internal Customer Relationship Management (ICRM) Print Gallery Publishers Print Gallery Publishers ISBN : 978-93-80406-31-2 First Edition 2011.

\section{National and International Journals}

1. Implications of Internal Marketing Strategies: An Empirical Analysis in Management Education Sector SMART Journal of Business Management Studies ISSN 0973-1598 / Vol-7 January-June 2011.

2. Status of Women Workers: An Empirical Study on HR Perspective JMS journal of management ad science. ISSN 2249-1260 / Vol-10 January-June 2014

Paper Presented in National / International / State Level Seminars

1. Strategic HR issues in small and medium enterprises National level seminar on "Business Eco System for Small and Medium Enterprises" Muthayammal Engineering College, Namakkal $29^{\text {th }} \& 30^{\text {th }}$ March 2012.

2. Customer Satisfaction Related to Healthcare Service in Global Era International Seminar on "Impact of LPG In Indian Business Scenario" AnnaiMathammalSheela Engineering College, Namakkal26 ${ }^{\text {th }}$ Feb 2011.

3. Recent Trends in Research on HR National Level Seminar on "Recent trends in research in HR" SNT Global Academy of Management Studies and Technology, Coimbatore29 $9^{\text {th }}$ Jan 2010.

4. Service Quality Enhancement as effective tool for business Education governance during financial downturn International Seminar on "Recent Trend in Capital Market and Financial Innovation" SMART Journal of Business Management Studies UGC Sponsored $9^{\text {th }} \& 10^{\text {th }}$ Jan 2010.

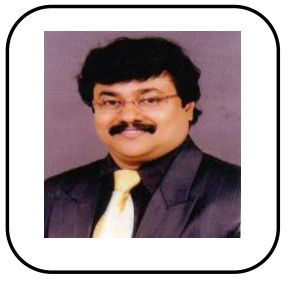

MY MISSION

Leave no stone un- turned, Up the Ante as pressure mounts and Behavioural Loyalty MISSION OUTCOME

Consistent Performance, Incremental Growth amidst transition, Retention of resources MY USP

Transformation Specialist

\section{CURRENT RESEARCH INTEREST}

Replacement vis-à-vis OEM: Seamless Market Integration Strategies

Digital Branding

Global Funding Proposal - Exploration

Bilstein, Thyssenkrupp AG, Germany

Ohlins, Sweden

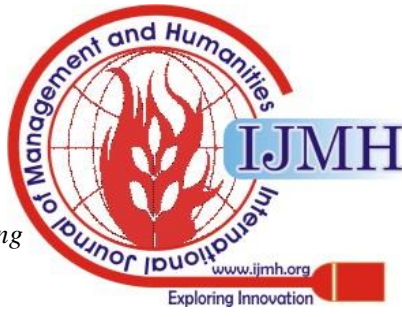


Total Experience

Industry -7

Academia - 20

$27 \quad$ Research Publications

Years Scopus Indexed - 11

Citations - 964

$\mathrm{H}$ - index - 4

Book Publications
Case Studies
Book chapters
Consultancy
Workshops
International MOU
Association Tie- ups
Industry Collaborations

Industry Collaborations

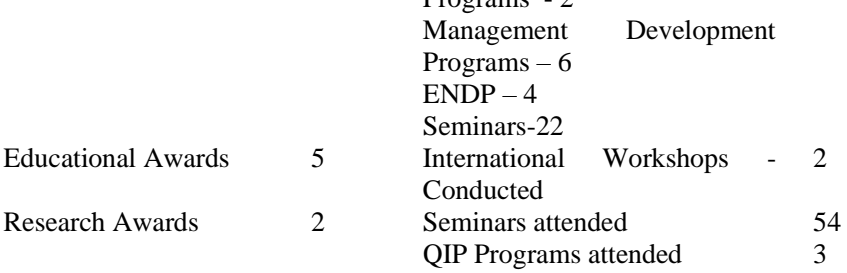

\section{EDUCATIONAL/ PROFESSIONAL QUALIFICATION} Commended], 2008

- M.Phil (Marketing), School of Management, Bharathiar University, Coimbatore, 2002

- MBA (Marketing), School of Management, Bharathiar University, Coimbatore, 1992

- BBA - APSA College, Madurai Kamaraj University, Madurai. [University Topper], 1989

• MIOD - Certified Member, Institute of Directors, 2017.

WORK EXPERIENCE

\begin{tabular}{|c|c|c|}
\hline Period & $\begin{array}{c}\text { Organization / Institute } \\
\text { Name }\end{array}$ & Designation \\
\hline 1992- 1996 & Sterling Group, Chennai & $\begin{array}{l}\text { Assistant Manager } \\
\text { - Sales \& Service }\end{array}$ \\
\hline $1996-1998$ & $\begin{array}{l}\text { Mahindra \& Mahindra Ltd, } \\
\text { Chennai }\end{array}$ & 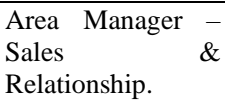 \\
\hline $1998-1999$ & CMSIMS, Coimbatore & Sr. Lecturers \\
\hline $1999-2004$ & \multirow{3}{*}{$\begin{array}{l}\text { Karunya Deemed University, } \\
\text { Coimbatore }\end{array}$} & Assistant Professor \\
\hline $2004-2012$ & & $\begin{array}{l}\text { Associate } \\
\text { Professor }\end{array}$ \\
\hline 2012 - Till Date & & Professor and Head \\
\hline
\end{tabular}

\section{BOOKS PUBLISHED}

- Customer Loyalty in Banking - ISBN 978-81-907783-29

- Indian Stock Market Analysis - ISBN 978-81-8465-043 -3

- Data Analysis for Business- ISBN 978-93-80406-29-9

- Loyalty in Indian Services Sector - ISBN 978-3-639-31613-1

- Organisational Behaviour and Management - ISBN 978-93-80406-35-0

- Internal Customer Relationship - ISBN 978-93-55709-29-9

\section{FUNDED PROJECTS}

- Designing Interactive Marketing Communication Modules for Promotion of Small and Micro Industries in Coimbatore District -ICSSR. (Completed) 5s.7.72 Lakhs

- ICSSR : Implementation of Online Marketing Strategies in MSMEs - Report Submitted - Rs.6 Lakhs

- Ongoing - DST - startup development assessment among smallpreneurs - Rs.3.25 Lakhs

\section{INTERNATIONAL OUTREACH}

- MOU with Kelaniya University, Srilanka

- MOU with Ben Gourien University, Israel
- Ph.D (Marketing), Bharathidasan University, Trichy. [Highly

\section{BOOK PUBLISHED}

- Introduction to Accounting Package (Tally 9.0) - August 2010, Akash Printers, Sivakasi

- Management Information System - August 2012, Sun Printers, Tiruchengode.

- Fundamentals of Computer \& Introduction to Accounting Package May 2016, Mithula Publications (ISBN No: 978-93-80506-14-2)

Effective Use of Social Media towards Business in Namakkal DT

Publisher: Online International Interdisplinary Journal

Website : [www.oiirj.org]

Impact Factor: 2.89

ISSN2249-9598, Volume-II, Issue-IV, July-Aug 2012

2. New Media Influence on Compact Car Purchasing Decision Making in

Tamilnadu: An Empirical

Study.

Publisher: Online International Interdisciplinary Journal

Website : [www.oiirj.org]

Impact Factor: 2.89

ISSN2249-9598, Volume-III, Issue-IV, Nov-Dec- 2013

3. A Comparative Study over Android and Windows 8 Mobile OS

Publisher: Online International Interdisplinary Journal

Website : [www.oiirj.org]

Impact Factor: 2.89

ISSN2249-9598, Volume-IV, Issue-I, Jan-Feb- 2014

\section{Published By:}

Blue Eyes Intelligence Engineering

\& Sciences Publication

DOI:10.35940/ijmh.B0382.104219

Journal Website: www.ijmh.org 
4. An Extensive Study over VBR Image Processing Algorithm Using

Headlight Prefetching and Mash

Video Sensing Techniques.

Publisher: Online International Interdisplinary Journal

Website : [www.oiirj.org]

Impact Factor: 2.89

ISSN2249-9598, Volume-IV, Issue-I, Jan-Feb- 2014

5. Appraise the consequence of internal marketing strategy for competitive advantage (case study:

motor pump industries)

Publisher: Elixir International Journal

Website: www.exilirpublishers.com

Impact Factor: 4.75

ISSN 2229 - 712X , January 2015.

6. Factors Influencing Online Purchasing Decision Among Students and Staff: A Survey in

Namakkal District.

Publisher: International Journal of Business and Administration Research Review

Website: www.ijbarr.org

Impact Factor: 3.07 